\title{
Retrospective study of Campylobacter-like organisms in patients undergoing partial gastrectomy
}

\author{
R J L F LOFFELD, * B C A J LOFFELD, J W ARENDS, J A FLENDRIG,* \\ J P VAN SPREEUWEL*
}

From the Departments of *Internal Medicine and Pathology, the University Hospital, Maastricht, The Netherlands

SUMMARY One hundred and five stoma biopsy specimens and 108 corpus biopsy specimens from 108 patients who had undergone a partial gastrectomy because of peptic ulcer disease were examined retrospectively for the presence of Campylobacter-like organisms and gastritis. In the corpus biopsy specimens Campylobacter-associated gastritis was found in $55(71 \%)$ of the cases and in $42(48 \%)$ of the stoma biopsy specimens. It is concluded that Campylobacter-like organisms have a role in gastritis after partial gastrectomy, although this role is more prominent in the corpus region. The role of Campylobacter pylori in peptic ulcer disease is not clinically important.

In 1984 Marshall and Warren first drew attention to the association between the presence of curved bacilli (Campylobacter pylori) and type B (antral) gastritis as well as peptic ulcers.' Since then this association has been amply confirmed, ${ }^{2-7}$ but a debate has been going on as to the clinical importance of the observation. Several questions remain unanswered. Does $C$ pylori have a pathogenetic role in gastritis and peptic ulcer disease or does it merely represent an epiphenomenom? Does Campylobacter-associated gastritis predispose to the development of gastric ulcers?

One way to address the second question is to study the fate of $C$ pylori in gastric mucosa after effective treatment for ulcers. If $C$ pylori were of pathogenetic importance in the pathogenesis of peptic ulcers through induction of gastritis a pronounced decline in or absence of the micro-organism would be expected under these circumstances.

In the era before the $\mathrm{H} 2$ receptor blocking drugs partial gastrectomy was regarded as the most effective treatment for peptic ulcer disease. Relapse of ulcers and the finding of gastritis in the gastric remnant was attributed to the reflux of bile. There are some data on the effect of treatment for gastritis on $C$ pylori, and they show a decrease in Campylobacter colonisation and a decrease in gastritis score. ${ }^{8}$ The eradication of $C$ pylori leads to a significant decrease in the relapse rate of duodenal ulcers. ${ }^{9}$ Little is known, however, about the fate of $C$ pylori after gastric surgery carried out because of peptic ulcer disease.

Accepted for publication 23 July 1988
O'Connor et al looked for Campylobacter-like organisms in patients with a partial gastrectomy ${ }^{10}$ and found that most were not colonised. A transition from Campylobacter-associated gastritis to reflux gastritis in the gastric remnant was suggested by these authors. Their material, however, consisted only of biopsy specimens taken from within $5 \mathrm{~cm}$ of the stoma and therefore the question as to whether $C$ pylori has a role in gastritis after partial gastric resection could not be properly addressed. In this paper we report on the presence of Campylobacter-like organisms in the stoma region as well as in the fundus of the gastric remnant.

\section{Material and methods}

Biopsy specimens from 108 patients who had undergone a partial gastrectomy (either the Billroth I or Billroth II type) because of peptic ulcer disease were studied. The patients comprised 92 men (mean age 63 years, range 35-86) and 16 women (mean age 60 years, range 30-75). All patients were seen in our endoscopy department during regular follow up. Twenty nine ( 24 men and five women) had a partial gastrectomy of Billroth I type and 79 (68 men and 11 women) had a Billroth II operation. The time between the operation and the examination of the follow up biopsy specimen ranged from two to 46 years.

Endoscopy was performed with the Olympus GIF Q or GIF $\mathbf{K}$ gastroscope, and biopsy specimens were taken from the stoma and from the corpus (gastric remnant), about $5 \mathrm{~cm}$ below the cardia, or halfway between the cardia and the stoma if the gastric 
remnant was small. All specimens were fixed in Bouin's solution. Sections were recut and stained with haematoxylin and eosin for histological grading of gastritis according to Whitehead ${ }^{11}$ and with a modified stain $^{1213}$ for the histological detection of Campylobacter-like organisms. Sections were regarded as positive for Campylobacter-like organisms if the typical curved bacilli were seen in the gastric mucus overlying the epithilium.

The presence of Campylobacter-like organisms was graded on a semiquantitative scale; grade $0=$ no bacteria detected; grade 1 = sporadic bacteria found; grade 2 = many bacteria found in almost all high power fields (400x); and grade $3=$ clusters of bacteria found in all high power fields.

Statistical analysis was performed by the $\chi^{2}$ test.

\section{Results}

Gastritis was present in $87(83 \%)$ of 105 stomal biopsy specimens (Whitehead grade 2 or 3 ). Of these, 42 (48\%) were positive for Campylobacter-like organisms (grade $1 / n=15$, grade $2 / n=13$, grade $3 /$ $n=14)$, and $45(52 \%)$ were negative for Campylobacter-like organisms. Eighteen biopsy specimens showed no signs of gastritis. Of these, $15(83 \%)$ were negative for Campylobacter-like organisms, three $(17 \%)$ were positive for Campylobacter-like organisms (grade 1/ $\mathrm{n}=1$, grade $2 / \mathrm{n}=2$ ). Campylobacter-like organisms were detected in 45 of $105(43 \%)$ stomal biopsy specimens.

Of 108 corpus biopsy specimens, $77(71 \%)$ were positive for gastritis (Whitehead grades 2 or 3), 55 (71\%) were positive for Campylobacter-like organisms (grade $1 / \mathrm{n}=18$, grade $2 / \mathrm{n}=13$, grade $3 /$ $\mathrm{n}=24)$, and $22(27 \%)$ were negative for Campylobacter-like organisms. Thirty one specimens had no signs of gastritis, $21(68 \%)$ were negative for Campylobacter-like organisms, and $10(32 \%)$ were positive for Campylobacter-like organisms (grade $1 / \mathrm{n}=6$, grade $2 / \mathrm{n}=2$, and grade $3 / \mathrm{n}=2$ ). Campylobacter-like organisms were detected in 65 of $108(60 \%)$ corpus biopsy specimens compared with 45 of $105(43 \%)$ stomal biopsy specimens $(p=0.01)$ (tables 1 and 2 ).

Less than 10 years after surgery, Campylobacterlike organisms were found in 12 of $17(70 \%)$ corpus biopsy specimens. This percentage did not change significantly the longer the interval after operation, with 53 of 91 specimens $(60 \%)$ remaining positive for Campylobacter-like organisms. In stomal biopsy specimens, however, a change occurred when the interval from operation was greater than 10 years. Before 10 years, nine of $15(60 \%)$ of stomal biopsy specimens were positive for Campylobacter-like organisms, but after 10 years this fell to 36 of $90(40 \%)$ $(p=0.0007)$.
Table 1 Association between histology and Campylobacterlike organisms

\begin{tabular}{|c|c|c|}
\hline & $\begin{array}{l}\text { No (\%) positive for } \\
\text { Campylobacter-like } \\
\text { organisms }\end{array}$ & $\begin{array}{l}\text { No (\%) negative for } \\
\text { Campylobacter-like } \\
\text { organisms }\end{array}$ \\
\hline $\begin{array}{l}\text { Gastritis present: } \\
\text { Stoma } \\
\text { Corpus }\end{array}$ & $\begin{array}{l}42(48 \cdot 3) \\
55(71 \cdot 4) \\
p=0.0004\end{array}$ & $\begin{array}{l}45(51 \cdot 7) \\
22(28 \cdot 6)\end{array}$ \\
\hline $\begin{array}{l}\text { Gastritis absent: } \\
\text { Stoma } \\
\text { Corpus }\end{array}$ & $\begin{array}{l}3(16 \cdot 6) \\
10(32 \cdot 2) \\
\text { NS }\end{array}$ & $\begin{array}{l}15(83 \cdot 4) \\
21(67 \cdot 8)\end{array}$ \\
\hline
\end{tabular}

Table 2 Association between biopsy site, histology, and grade of presence of Campylobacter-like organsisms

\begin{tabular}{|c|c|c|c|c|}
\hline & Grade 0 & Grade 1 & Grade 2 & Grade 3 \\
\hline $\begin{array}{l}\text { Stoma: } \\
\text { Gastritis present } \\
\text { Gastritis absent }\end{array}$ & $\begin{array}{l}45 \\
15 \\
p=0.07\end{array}$ & $\begin{array}{r}15 \\
1\end{array}$ & $\begin{array}{r}13 \\
2\end{array}$ & $\begin{array}{r}14 \\
0\end{array}$ \\
\hline $\begin{array}{l}\text { Corpus: } \\
\text { Gastritis present } \\
\text { Gastritis absent }\end{array}$ & $\begin{array}{l}22 \\
21 \\
p=0.00\end{array}$ & $\begin{array}{r}18 \\
6 \\
01\end{array}$ & $\begin{array}{r}13 \\
2\end{array}$ & $\begin{array}{r}24 \\
2\end{array}$ \\
\hline
\end{tabular}

Table 3 Association between histology, type of resection, and Campylobacter-like organsisms

\begin{tabular}{lcc}
\hline & $\begin{array}{c}\text { Billroth I } \\
(n=29)\end{array}$ & $\begin{array}{c}\text { Billroth II } \\
(n=79)\end{array}$ \\
\hline Gastritis & $25(86)$ & $70(89)$ \\
No gastritis & $4(14)$ & $9(11)$ \\
Positive for Campylobacter-like organisms & $21(72)$ & $51(65)$ \\
Negative for Campylobacter-like organisms $8(28)$ & $28(35)$ \\
& $p=\mathrm{NS}$ & \\
\hline
\end{tabular}

Table 3 shows that there was no difference between the type of operation and presence of Campylobacterlike organisms or gastritis.

In the absence of gastritis in the corpus or stomal biopsy specimens we found either normal histology $(n=26)$, atypia $(n=10)$, intestinal metaplasia $(n=16)$, or atrophy $(n=10)$. Atypia and intestinal metaplasia were almost entirely confined to the specimens negative for Campylobacter-like organisms, atrophy and normal histology were found in specimens either positive or negative for Campylobacter-like organisms.

\section{Discussion}

The effect of gastric surgery (Billroth I and II operation) on Campylobacter colonisation has been studied in two reports. The authurs found evidence of Campylobacter-like organisms in $26 \%{ }^{13}$ and in $34 \%,{ }^{15}$ 
respectively, and concluded that $C$ pylori did not have a role in post-gastrectomy gastritis. After measurement of bile contents in the gastric remnant they concluded that $C$ pylori was eradicated by bile reflux and that reflux gastritis was induced. Only biopsy specimens taken from within $5 \mathrm{~cm}$ of the stoma were studied. In keeping with these data we observed a prevalence of $43 \%$ for Campylobacter-like organisms in the stomal biopsy specimens which rose to $60 \%$ in the corpus biopsy specimens.

Our data also indicate that in the corpus the presence of Campylobacter-like organisms seemed to be substantially associated with gastritis; $71 \%$ of the biopsy specimens showing gastritis were positive for Campylobacter-like organisms. By contrast, stomal gastritis was less often associated with Campylobacter-like organisms as more than half of the specimens with gastritis were negative for Campylobacter-like organisms. This suggests that the disruption of the mucosal barrier by bile reflux and subsequent development of microenvironment unfavourable to colonisation by $C$ pylori, will probably be responsible for the gastritis. In cases without gastritis there was no significant difference in the presence of Campylobacter-like organisms between corpus and stoma biopsy specimens.

These obervations suggest that Campylobacterassociated gastritis persists in the corpus region after partial gastrectomy. The difference in the prevalence of Campylobacter-like organisms between the stoma and the corpus biopsy specimens could not be explained by differences in the prevalence of intestinal metaplasia.

After surgery certain histological features are correlated with the reflux of bile in the stomach. ${ }^{14}$ Atypia is often considered to be a sign of regeneration because of bile reflux. In the absence of gastritis we found atypia in the group negative for Campylobacter-like organisms, which suggests bile reflux is responsible for the absence of $C$ pylori. Cases of intestinal metaplasia were found in the group negative for campylobacter-like organisms: $C$ pylori is thought to have a special affinity for the gastric mucosa.

The observation of O'Connor $e t$ al that the presence of Campylobacter-like organisms was influenced by lengths of interval from operation ${ }^{10}$ could only partly be confirmed by our data. The prevalence of Campylobacter-like organisms after a short interval was higher, but this was only true for the stomal biopsy specimens, no statistical difference being found in corpus biopsy specimens compared after long or short follow up.

There was no difference in prevalence of Campylobacter-like organisms between Billroth I and II resection specimens.
In conclusion, we detected a Campylobacterassociated gastritis in a high number of patients after gastric surgery for peptic ulcer disease which suggests that this organism still has a role in gastritis in the partially resected stomach, although this role is more prominent in the gastric remnant than in the stoma region. As apparently the therapeutic effect of partial gastrectomy on gastric ulcers cannot be explained by a decrease of Campylobacter-associated gastritis, this argues against the theory that $C$ pylori as a single factor in the pathogenesis of peptic ulcer disease. The exact role of $C$ pylori in gastritis, however, remains to be elucidated.

\section{References}

1 Marshall BJ, Warren JR. Unidentified curved bacilli in the stomach of patients with gastritis and peptic ulceration. Lancet 1984;i:1311-14.

2 Jones DM, Lessels AM, Eldridge J. Campylobacter like organisms on the gastric mucosa: culture, histological and serological studies. J Clin Pathol 1984;37:1002-6.

3 Axon ATR. Campylobacter pyloridis: what role in gastritis and peptic ulcer. Br Med J 1986;293:772.

4 Rathbone BJ, Wyatt JI, Heatly RV. Campylobacter pyloridis: a new factor in peptic ulcer disease. Gut 1986;27:635-41.

5 Loffeld RJLF, Potters HVPJ, Arends JW, Stobberingh E, Flendrig JA, van Spreeuwel JP. Campylobacter-associated gastritis in patients with non-ulcer dyspepsia. J Clin Pathol 1988;41:85-8.

6 Rathbone BJ, Wyatt JL, Worsley BW, et al. Systemic and local immune responses to gastric Campylobacter pyloridis in nonulcer dyspepsia. Gut 1986;27:642-7.

7 Booth L, Holdstock G, McBride H, et al. Clinical importance of Campylobacter pyloridis and associated serum IgA and IgG antibody responses in patients undergoing upper gastrointestinal endoscopy. J Clin Pathol 1986;39:215-19.

8 McNulty AM, Geanty JC, Crump B et al. Campylobacter pyloridis and associated gastritis: investigator blind placebo controlled trial of Bismuth-salicylate and erythromycine ethylsuccinate. Br Med J 1986;293:645-9.

9 Coghlan JG, Humphries H, Dooley C, et al. Campylobacter pylori and the recurrence of duodenal ulcers, a 12-month follow-up study. Lancet 1987;i:1109-11.

10 O'Connor HJ, Wyatt JI, Ward DC, et al. Effect of duodenal ulcer surgery and enterogastric reflux on Campylobacter pyloridis. Lancet 1986;ii:1178-81.

11 Whitehead R. Mucosal biopsy of the gastrointestinal tract. In: Bennington JL, ed. Major problems in pathology, vol III. 2nd ed. Philadelphia: W S Saunders, 1979.

12 Potters HVPJ, Loffeld RJLF, Stobberingh E, van Spreeuwel JP, Arends JW. Rapid staining of Campylobacter pyloridis. Histopathology 1987;11:1233.

13 Gray SF, Wyatt JI, Rathbone BJ. Simplified techniques for identifying Campylobacter pyloridis. $J$ Clin Pathol 1986;39:1279-80.

14 Dixon MF, O'Connor HJ, Axon ATR, King RFGJ, Johnston D. Reflux gastritis-distinct histological entity. J Clin Pathol 1986;39:524-30.

Requests for reprints to: Dr R J L F Loffeld, University Hospital, Maastricht, PO Box 1918, 6201 Maastricht, The Netherlands. 